\title{
Laparoscopic cholecystectomy for mild acute gallstone pancreatitis-indication itself is a good predictor of (minimal) intraoperative difficulty-a retrospective cohort study
}

\author{
Ishaan Maitra ${ }^{1}$ (D), Grace Bennett ${ }^{1}$ (D), Camilo Morais² (D), Ravindra Date ${ }^{1}$ (D) \\ ${ }^{1}$ Department of General Surgery, Lancashire Teaching Hospitals, Preston, United Kingdom \\ ${ }^{2}$ University of Central Lancashire School of Pharmacy and Biomedical Sciences, Preston, United Kingdom
}

\section{ABSTRACT}

Objective: The literature predicting difficulties during Laparoscopic Cholecystectomy (LC) for Acute Gallstone Pancreatitis (AGP) is mainly focused on the timing of operation. In our experience, LC for AGP is rarely difficult irrespective of the timing of operation. The aim of this study was to assess intraoperative difficulties in mild AGP patients to verify this observation.

Material and Methods: A retrospective analysis of all consecutive patients who underwent LC for mild AGP between 2014 and 2018 in a single centre was performed. Patients with known alcohol abuse, post-endoscopic retrograde cholangiopancreaticography (ERCP) induced pancreatitis, and those with chronic pancreatitis were excluded. Univariate weighted analysis was performed with 11 factors, with a linear threshold boundary defined as the mean distance between the four degrees of difficulty (DoD 1-4).

Results: Ninety-six patients (Male $=33$, median age $=56 ;$ Female $=63$, median age $=52$ ) were analysed. Majority of the patients were an ASA of two $(n=50 ; 52 \%)$ with a median BMI of 28 (range 18-50). Five procedures were technically difficult ( $D \circ D \geq 3$ ) and only one procedure was converted to open operation. Univariate analysis showed that duration of pancreatitis $>6$ days $(p=0.002)$ and evidence of acute cholecystitis $(p<0.05)$ are associated with a difficult $L C(D o D \geq 3)$. The rest of the factors did not influence DoD.

Conclusion: Based on this result, we suggest that LC for mild AGP is rarely difficult, and this finding can be used in practice for selecting these patients for training lists.

Keywords: Acute gallstone pancreatitis, degree of difficulty, laparoscopic cholecystectomy

Cite this article as: Maitra I, Bennett G, Morais C, Date R. Laparoscopic cholecystectomy for mild acute gallstone pancreatitis- indication itself is a good predictor of (minimal) intraoperative difficulty- a retrospective cohort study. Turk J Surg 2021; 37 (2): 103-108.

\section{Corresponding Author}

Ravindra Date

E-mail: ravidate@hotmail.com

Received: 05.06.2020

Accepted: 07.03.2021

Available Online Date: 30.06.2021

o Copyright 2021 by Turkish Surgical Society Available online at www.turkjsurg.com

DOI: $10.47717 /$ turkjsurg.2021.5084

\section{INTRODUCTION}

Common indications for Laparoscopic cholecystectomy (LC) can be broadly categorised based on the organs affected by gallstones. These include the gallbladder (biliary colic or acute cholecystitis), common bile duct (obstructive jaundice or cholangitis) and pancreas (gallstone pancreatitis).

The Degree of Difficulty (DoD) during LC varies widely, and surgeons have attempted to develop scoring systems to predict intraoperative difficulties (1-3). Our group has been working on predicting these difficulties and has presented our findings in the literature. Our first paper suggested that C-Reactive Protein (CRP) is the single most useful predictor in difficult LC's (4). CRP, being a reliable marker of inflammation, predicts the difficulties secondary to inflammation of gallbladder (due to stones in gallbladder itself). Our second study suggested that the "indication"along with the degree of inflammation encountered aids in the prediction of intraoperative difficulties during LC (5). Furthermore, this finding was based on our observation that $L C$ was rarely difficult in patients with mild acute gallstone pancreatitis.

A recent multicentre prospective randomised trial of 249 patients by da Costa DW. et al. (6) has investigated risk factors for difficult LC's for mild acute gallstone pancreatitis (AGP). The authors have established that male sex, previous endoscopic sphincterotomy and delaying cholecystectomy for more than two weeks predicted a difficult LC after mild AGP (6). They have further clarified that the probability 
of difficulty was increased from $18 \%$ to $55 \%$ when these factors were present.

These findings are contrary to our previous studies (that was not specific for AGP) which suggested that LC for AGP is generally not difficult irrespective of the timing of the operation (5). The number of patients with mild AGP in this study was relatively small. We have, however, subsequently observed the same trend in our current practice.

The aim of this study was to assess intraoperative difficulties in mild AGP patients to verify the findings of our previous study.

\section{MATERIAL and METHODS}

This is a single centre retrospective case note study of all consecutive patients who underwent Laparoscopic Cholecystectomy for Acute Gallstone Pancreatitis between 2014 and 2018. Patients were identified from a prospectively kept database of operations and from the internal trust coding department at the Trust. IRB approval was not applicable.

The Atlanta classification was utilised in identifying patients with mild AGP. Mild AGP is defined as an absence of organ failure or the presence of organ failure that does not exceed 48 hours in duration) (7). Patients with known alcohol abuse and those with chronic as well as severe pancreatitis were excluded.

Key demographic, clinical and surgical data were identified from prospectively kept database as well as case notes. Clinical data included Body Mass Index (BMI), ASA, a prior history of biliary colic or cholecystitis, pancreatitis or upper abdominal surgery. Further clinical information collected included a history of previous ERCP, complications at ERCP (if any), the number of days between sphincterotomy (if any), the number of days between admission and LC (and reasons for delay $>50$ days), and the duration of pancreatitis (number of days between admission and discharge, excluding days in hospital eluding to a social delayed discharge). Surgical data included the degree of difficulty of LC (primary outcome measure-documented or inferred from operation notes on the Evolve ${ }^{\mathrm{TM}}$ database to allow uniformity in the data set) operating time, the reason for conversion and the histology of the specimen after operation.

The difficulty of cholecystectomy was ascertained using the Nassar scale interpreted from the operative notes and findings (grades 1-4) (8). This scale was published in 1995 and grades operative findings from the gallbladder, cystic pedicle and associated adhesions. A difficult $L C$ was indicated by a $D o D \geq 3$.

Data analysis was performed within a MATLAB R2014b environment (MathWorks Inc., USA). P-values were estimated based on an ANOVA tests for univariate and multivariate comparisons. Multivariate analysis was performed with 13 factors (male sex, age, presenting complaint, BMI, ASA, prior pancreatitis, prior biliary colic, evidence of cholangitis, evidence of cholecystitis at operation, history of upper abdominal surgery, prior ERCP, days between admission and cholecystectomy, and duration of pancreatitis) by means of multiple linear regression (MLR), with a linear threshold boundary defined as the mean distance between the two predicted clusters ( $D \circ D \leq / \geq 3$ ). Multivariate analysis is employed when the data have non-linearity or non-distinguishing features in unique variables (e.g., when employing univariate analysis), when the signal is complex and composed of overlapping features, or when the data changes over time or by other physical parameters (9). MLR is a well-known multivariate regression method where the weights for the input variables are calculated in at least-squares fashion. The predicted response is obtained by multiplying the regression coefficients by the original variables used for model construction. The data was auto-scaled before analysis to normalise the influence of different units into the model.

This study is reported in line with the STROCSS criteria (10).

\section{RESULTS}

Ninety-six patients with mild AGP were included in the study.

Patient Demographics and Clinical data are summarised in Table 1 and Table 2 respectively.

Three patients had previous upper abdominal surgery. All had a midline laparotomy wound (Left Hemicolectomy; Hartmann's

\begin{tabular}{|l|c|}
\hline \multicolumn{2}{|l|}{ Table 1. Demographics $(n=96)$} \\
\hline Age (range and median) & $21-85(54.5)$ \\
\hline Male sex (n/\%) & $33(34)$ \\
\hline ASA $1(n / \%)$ & $24(25)$ \\
\hline ASA 2 (n/\%) & $50(52)$ \\
\hline ASA 3 (n/\%) & $21(22)$ \\
\hline ASA 4 (n/\%) & $1(1)$ \\
\hline BMI (range and median) & $18-50(28)$ \\
\hline
\end{tabular}

Table 2. Clinical data $(n=96)$

Previous documented evidence of biliary colic (history) (n/\%)

Previous documented evidence of cholecystitis (imaging) $(n / \%)$

\begin{tabular}{|l|c|}
\hline Previous documented cholangitis (history) (n/\%) & $1(1)$ \\
\hline Previous upper abdominal surgery (n/\%) & $3(3)$ \\
\hline Prior ERCP to LC (n/\%) & $12(13)$ \\
\hline $\begin{array}{l}\text { Number of days between sphincterotomy (if } \\
\text { performed) and LC (range and median) }\end{array}$ & $1-147(14)$ \\
\hline $\begin{array}{l}\text { Number of days between AGP admission and LC } \\
\text { (range and median) }\end{array}$ & $2-365(18)$ \\
\hline Duration of pancreatitis (range and median) & $2-10(5)$ \\
\hline
\end{tabular}


Table 3. Degree of difficulty $(n=96)$ and operating time

\begin{tabular}{|l|c|c|}
\hline & $\mathbf{n}(\%)$ & $\begin{array}{c}\text { Operating time in minutes median } \\
\text { (minimum/maximum) }\end{array}$ \\
\hline DoD 1 & $60(63)$ & $36(26,58)$ \\
\hline DoD 2 & $31(32)$ & $62(60 / 110)$ \\
\hline DoD 3 & $4(4)$ & $72(62 / 140)$ \\
\hline DoD 4 & $1(1)$ & $125(121 / 130)$ \\
\hline
\end{tabular}

Table 4. $p$ value for univariate analysis of DoD of each clinical parameter among all patients $(p<0.05$ is statistically significant; $p<0.001$ is statistically highly significant)

\begin{tabular}{|l|c|}
\hline Clinical parameter & DoD $\geq \mathbf{3}($ mean $\pm 95 \%$ Cl) \\
\hline Male sex & $\mathrm{p}=0.697$ \\
\hline Age (21 to 85) & $\mathrm{p}=0.897(53 \pm 3.2)$ \\
\hline ASA (1 to 4) & $\mathrm{p}=0.961(2 \pm 0.1)$ \\
\hline BMI (18-49) & $\mathrm{p}=0.837(30 \pm 1.4)$ \\
\hline $\begin{array}{l}\text { Previous documented evidence } \\
\text { of biliary colic }\end{array}$ & $\mathrm{p}=0.747$ \\
\hline Previous history of cholangitis & $\mathrm{p}=0.616$ \\
\hline $\begin{array}{l}\text { History of upper abdominal } \\
\text { surgery }\end{array}$ & $\mathrm{p}=0.101$ \\
\hline Prior ERCP to LC & $\mathrm{p}=0.350(60 \pm 16.6)$ \\
\hline $\begin{array}{l}\text { Number of days between AGP } \\
\text { admission and LC }\end{array}$ & $\mathrm{p}=0.04$ \\
\hline Evidence of acute cholecystitis & $\mathrm{p}=0.002(6 \pm 0.8)$ \\
\hline Duration of pancreatitis in days & \\
\hline
\end{tabular}

for perforated Diverticular disease; previously perforated duodenal ulceration).

Only one patient had documented cholangitis but did not require subsequent ERCP.

Twelve patients had a prior ERCP to their LC. One patient had an unsuccessful ERCP and sphincterotomy. The documented reason for this was that the gastroenterologist was unable to cannulate the CBD safely.

It was established that 22 patients (23\%) had a delay between their initial AGP diagnosis and LC of over 50 days. Only one patient in this cohort had a difficult $L C(D \circ D=3)$. It was determined that non-compliance to recommendations for early LC were a combination of patients needing further optimisation/investigations prior to $L C(n=6 ; 27 \%)$, patient choice to delay $L C(n=3$; $14 \%)$, and pregnancy in AGP pertaining delay to $L C(n=2 ; 9 \%)$. The major limiting factor was hospital resources and day bed availability ( $n=11 ; 50 \%)$.

The degree of difficulty and operating times are shown in Table 3.
Five percent of the patients ( $n=5$ ) had a DoD from 3 or 4 (difficult $\mathrm{LC}$ ). The patient with a DoD of four was converted. The reasons for conversion outlined evidence of cholecystitis with Calot's being impossible to clarify with dense adhesions between Calot's and the duodenum.

Histologically, all 96 patients had a degree of chronic cholecystitis. The only patient, who had LC converted to open with DoD 4, had histological diagnosis of acute on chronic cholecystitis.

Uni and Multivariate analyses of predictive factors for conversion Based on a univariate comparison using ANOVA testing, factors found to be significant in predicting a difficult $L C(D \circ D \geq 3)$ were a duration of pancreatitis $>6$ days and evidence of acute cholecystitis at operation, which were all statistically significant $(p<0.05)$. All other factors did not influence $D o D \geq 3$ (Table 4).

As expected, the operation time behaved approximately linear $(R=0.975)$ with DoD (Figure 1), where larger operation times were associated with larger DoD values. In addition, all DoD values (1-4) were statistically highly significant from each other based on the operation time alone $(p<0.001)$, thus this factor alone can be used to estimate the DoD.

\section{DISCUSSION}

This retrospective case note review showed that only five (5\%) LC's out of 96 for mild AGP from 2014 to 2018 was 'difficult' (DoD $\geq$ 3) due to associated acute cholecystitis and required conversion.

Three previous studies have been directed on assessing difficulty of LC after mild AGP (11-13). Difficulty ranged from 18 to $33 \%$ in these studies. This is in contrast to our findings of only five patients (5\%) which had difficult procedures regardless of timings of surgery after the primary diagnosis of mild AGP.

We propose a theory for our finding of ease of $L C$ for mild AGP. Most patients with mild AGP have small gallstone/sludge that passes easily through a wide cystic duct resulting in transient obstruction of sphincter of Oddi and pancreatitis. A wide cystic duct is unlikely to become obstructed by stones making biliary colic or cholecystitis less likely in these patients. This may be a possible aetiological theory as to why mild AGP patients rarely have gallbladder inflammation and why these patients do not present difficulties during LCS. 


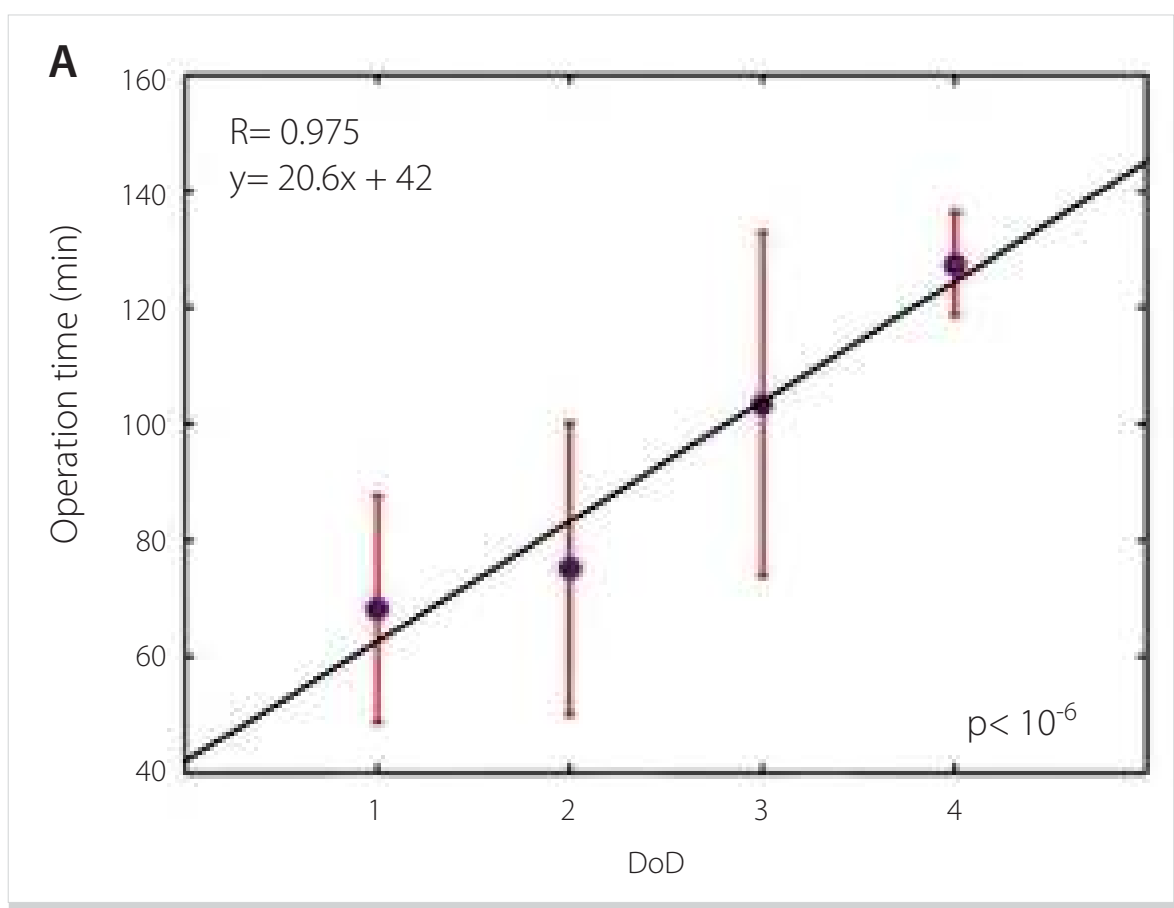

Figure 1. Correlation between DoD and operation time.

The only patient whose LC was converted to open had acute cholecystitis that resulted in difficulty in visualisation of Calot's and subsequent conversion. This finding again suggests that AGP itself does not increase the DoD in LC but associated GB pathology does.

A recent prospective study of a U.K. database of 8820 patients advocates a six-point scoring system for prediction of operative difficulty during LC (14). The system gives a maximum of threepoints for the indication for the procedure. The system scores zero if the indication is AGP. Other scoring systems also give low scores for pancreatitis as a prognostic factor for a difficult LC $(15,16)$. This correlates well with our study findings.

Further analysis of our data showed that a duration of pancreatitis $>6$ days ( $p=0.002$ ) and evidence of acute cholecystitis ( $p<$ 0.05 ) were associated with DoD $\geq 3$. Other implicated independent risk factors such as male sex or evidence of previous ERCP in the current literature were not statistically significant in the prediction of difficulty or conversion. This is contrary to previous studies and data sets $(1,2)$.

Some studies have used operative time as a surrogate marker of difficulty. Operating time, no matter how highly dependent on surgical skill and institutional policies, precludes direct comparison amongst surgeons and in between centres $(17,18)$.

The established Nassar operative difficulty scale was utilised in our study as this has been found to be a significant independent predictor of operative duration, conversion to open surgery, 30day complications and 30-day reintervention (all $p<0.001$ ) (3).
Our group further looked at the patients with severe AGP in this timeframe. We found three patients who had severe AGP with evidence of pancreatic necrosis on CT Imaging. Two were females, one was male, and the age range of patients was between 51 and 58 (median 52). All were ASA 2 with a $\mathrm{BMl}<28$.

Only one patient with severe AGP had an intraoperative of DoD 4 and had a "laparoscopic converted to open" cholecystectomy. The operation note documented "unable to see Calot's triangle safely" as well as "acute cholecystitis". This was confirmed on histology.

AGP related LC form 5-10\% of all the LC done in this institute and this simple negative predictor of difficulty helps us to select the patients for training lists.

The main limitation of this study is wide variation in timing of operation after primary diagnosis of AGP and LC (between two and 150 days) for the reasons mentioned above. Though retrospective in nature, most of the data in this study was obtained from a prospectively driven database. Findings of a correlation between AGP and operative difficulty would not have been different if the study were to be prospective.

\section{CONCLUSION}

In conclusion, our results clearly indicate that LC for mild AGP should not be difficult unless there is evidence of concurrent acute cholecystitis. This simple negative predictor can be used for selection of patients for training lists. 
Ethics Committee Approval: It is stated by NHS Lancashire Teaching Hospitals that this study is considered to be Service Evaluation which means designed and conducted care and does not require ethical review.

Peer-review: Externally peer-reviewed.

Author Contributions: Concept - R.D.; Design - R.D.; Supervision - R.D.; Data Collection and/or Processing - I.M., G.B.; Analysis and/or Interpratation - C.M.; Literature Review - R.D., I.M.; Writing Manuscript - I.M.; Critical Reviews - I.M., R.D.

Conflict of Interest: The authors declare that they have no conflict of interest.

Financial Disclosure: The authors declared that this study has received no financial support.

\section{REFERENCES}

1. Zisman A, Gold-Deutch R, Zisman E, Negri M, Halpern Z, Lin G, et al. Is male gender a risk factor for conversion of laparoscopic into open cholecystectomy? Surg Endosc 1996; 10(9): 892-4. [CrossRef]

2. Reinders JS, Gouma DJ, Heisterkamp J, Tromp E, van Ramshorst B, Boerma D. Laparoscopic cholecystectomy is more difficult after a previous endoscopic retrograde cholangiography. HPB (Oxford) 2013; 15(3): 230-4. [CrossRef]

3. Griffiths EA, Hodson J, Vohra RS, Marriott P, Katbeh T, Zino S, et al. West Midlands Research Collaborative. Utilisation of an operative difficulty grading scale for laparoscopic cholecystectomy. Surg Endosc 2019; 33(1): 110-21. [CrossRef]

4. Mok KW, Reddy R, Wood F, Turner P, Ward JB, Pursnani KG, et al. Is $C$-reactive protein a useful adjunct in selecting patients for emergency cholecystectomy by predicting severe/gangrenous cholecystitis? Int J Surg 2014, 12(7): 649-53. [CrossRef]

5. Date RS, Gerrard AD. Inflammation and indication: a novel approach to predict degree of difficulty during emergency laparoscopic cholecystectomy. J Minim Access Surg 2018, 14(4): 362-4. [CrossRef]

6. da Costa DW, Schepers NJ, Bouwense SA, Hollemans RA, van Santvoort HC, Bollen TL, et al. Dutch Pancreatitis Study Group. Predicting a 'difficult cholecystectomy' after mild gallstone pancreatitis. HPB (Oxford) 2019; 21(7): 827-33. [CrossRef]
7. Banks PA, Bollen TL, Dervenis C, Gooszen HG, Johnson CD, Sarr MG, et al. Classification of acute pancreatitis 2012: revision of the Atlanta classification and definitions by international consensus. Gut 2013, 62(1): 102-11. [CrossRef]

8. Nassar AHM, Ashkar KA, Mohamed AY, Hafiz AA. Is laparoscopic cholecystectomy possible without video technology? Minim Invasive Ther Allied Technol; 1995, 4(2): 63-5. [CrossRef]

9. Rencher AC, Christensen WF. Methods of Multivariate Analysis. $2^{\text {nd }}$ ed. New York: John Wiley \& Sons, 2002;157. [CrossRef]

10. Agha R, Abdall-Razak A, Crossley E, Dowlut N, losifidis C, Mathew G, et al. The STROCSS 2019 Guideline: Strengthening the reporting of Cohort studies in surgery. IJS 2019; 72: 156-65. [CrossRef]

11. Sinha R. Early laparoscopic cholecystectomy in acute biliary pancreatitis: the optimal choice? HPB 2008; 10(5): 332-5. [CrossRef]

12. Tate JJ, Lau WY, Li AK. Laparoscopic cholecystectomy for biliary pancreatitis. BJS 2006; 81(5): 720-2. [CrossRef]

13. Schachter P, Peleg T, Cohen O. Interval laparoscopic cholecystectomy in the management of acute biliary pancreatitis. HPB Surg 2000, 11(5): 319-22; discussion 322-3. [CrossRef]

14. Sutcliffe RP, Hollyman M, Hodson J, Bonney G, Vohra RS, Griffiths EA, et al. Preoperative risk factors for conversion from laparoscopic to open cholecystectomy: a validated risk score derived from a prospective U.K. database of 8820 patients. HPB (Oxford) 2016; 18(11): 922-8. [CrossRef]

15. Goonawardena J, Gunnarsson R, de Costa A. Predicting conversion from laparoscopic to open cholecystectomy presented as a probability nomogram based on preoperative patient risk factors. Am J Surg 2015: 210(3): 492-500. [CrossRef]

16. Vivek MA, Augustine AJ, Rao R. A comprehensive predictive scoring method for difficult laparoscopic cholecystectomy. J Minim Access Surg 2014, 10(2): 62-7. [CrossRef]

17. Schrenk P, Woisetschläger R, Rieger R, Wayand WU. A diagnostic score to predict the difficulty of a laparoscopic cholecystectomy from preoperative variables. Surg Endosc 1998; 12(2): 148-50. [CrossRef]

18. Hiromatsu T, Hasegawa H, Sakamoto E, Komatsu S, Kawai K, Tabata $T$, et al. Preoperative evaluation of difficulty of laparoscopic cholecystectomy. Jpn J Gastroenterol Surg 2007; 40(8): 1449-55. [CrossRef] 


\section{ORIJINAL ÇALIŞMA-ÖZET}

Turk J Surg 2021; 37 (2): 103-108

\section{Hafif akut safra taşı pankreatitinde laparoskopik kolesistektomi-endikasyonun kendisi (minimal) intraoperatif zorluğun iyi bir prediktörüdür-retrospektif bir kohort çalışması}

Ishaan Maitra ${ }^{1}$, Grace Bennett ${ }^{1}$, Camilo Morais ${ }^{2}$, Ravindra Date ${ }^{1}$

${ }^{1}$ Lancashire Eğitim Hastaneleri, Genel Cerrahi Anabilim Dalı, Preston, Birleşik Krallık

${ }^{2}$ Central Lancashire Üniversitesi, Eczacılık ve Biyomedikal Bilimler Fakültesi, Preston, Birleşik Krallık

\section{ÖZET}

Giriş ve Amaç: Akut safra taşı pankreatiti (AGP) için laparoskopik kolesistektomi (LC) sırasındaki zorlukları tahmin eden literatür, esas olarak operasyonun zamanlamasına odaklanmıştır. Deneyimlerimize göre, AGP için LC, operasyonun zamanlamasına bakılmaksızın nadiren zordur. Bu çalışmanın amacı, bu gözlemi doğrulamak için hafif AGP hastalarında intraoperatif zorlukları değerlendirmektir.

Gereç ve Yöntem: 2014-2018 yılları arasında hafif AGP nedeniyle LC uygulanan ardışık tüm hastaların tek bir merkezde retrospektif analizi yapıldı. Alkol kötüye kullanımı olduğu bilinen hastalar, Endoskopik retrograd kolanjiyopankreatikografi (ERCP) ile indüklenen pankreatit ve kronik pankreatiti olanlar hariç tutuldu. Dört zorluk derecesi (DoD 1-4) arasındaki ortalama mesafe olarak tanımlanan doğrusal bir eşik sınırı ile 11 faktörle tek değişkenli ağırıklı analiz yapıldı.

Bulgular: Altmış altı hasta (Erkek= 33, medyan yaş= 56; Kadın $=63$, medyan yaş= 52) analiz edildi. Hastaların çoğunluğu, medyan BMı 28 (aralık 18-50) olan 2 ASA (N=50; \%52) idi. Sadece bir hastada DoD 4 vardı ve açık operasyona dönüştürüldü. Tek değişkenli analiz, pankreatit süresinin $>6$ gün $(p=0,002)$ ve akut kolesistit kanıtının $(p<0,05)$ DoD $>3$ veya dönüşüm ile ilişkili olduğunu gösterdi.

Sonuç: Bu sonuca dayanarak, hafif AGP için LC'nin nadiren zor olduğunu ve bu bulgunun pratikte bu hastaların eğitim listeleri için seçilmesinde kullanılabileceğini önermekteyiz.

Anahtar Kelimeler: Akut safra taşı pankreatiti, zorluk derecesi, laparoskopik kolesistektomi

Doi: 10.47717/turkjsurg.2021.5084 